\title{
Kentsel yeşil alanların peyzaj ve eko-silvikültürel yönden incelenmesi: Trabzon örneği
}

\author{
Investigation of urban green areas from landscape and eco-silvicultural aspects: the sample \\ of Trabzon
}

\author{
İbrahim TURNA ${ }^{1, a}$, Tuğba SEVIMLí2,b, Nebahat YILDIRIM ${ }^{* 1, c}$ \\ ${ }^{1}$ Karadeniz Teknik Üniversitesi, Orman Fakültesi, Orman Mühendisliği Bölümü,61080, Trabzon \\ ${ }^{2}$ Peyzaj Mimarı, Orman Yüksek Mühendisi, 34862, İstanbul
}

• Geliş tarihi / Received: 18.11.2020 • Düzeltilerek geliş tarihi / Received in revised form: 04.02.2021 • Kabul tarihi / Accepted: 28.02 .2021

\begin{abstract}
$\ddot{O} z$
Kentsel yeşil alanların peyzaj, ekoloji ve silvikültürel yönden değerlendirildiği bu çalışmada; Trabzon kent merkezinde bulunan Atatürk Köşkü Ormanı, Lütfi Göktaş Parkı (Ekopark) ve Boztepe Ormanı olmak üzere üç adet kentsel yeşil alan değerlendirilmiştir. $\mathrm{Bu}$ alanların meşcere karakteristikleri ile ekolojik ve peyzaj özellikleri incelenmiştir. Araştırma alanlarını temsil edecek örnek alanlar seçilmiş ve bu alanlarda toplamda 10 adet toprak çukuru (46 adet toprak örneği) ve 9 adet meşcere profili alınmıştır. Elde edilen verilere göre, yeşil alanların kullanım biçimleri, işlevselliği, yeterliliği gibi özellikler değerlendirilmiştir. Çalışma sonucunda; her üç alanın toprak bakımından kil oranının yüksek olduğu görülmüştür. Atatürk Köşkü ve Boztepe Ormanın bitki türü bakımından sınırlı sayıda iken Lütfi Göktaş Parkında ise daha fazla olduğu tespit edilmiştir. Üç alanda da tesis aşamasında ağaç türü seçiminde yetişme ortamı özelliklerine tam olarak uyulmadığı, bunun sonucu olarak kurumaların meydana geldiği anlaşılmaktadır. Bu nedenle de çalışmanın yapıldığı tarihten (2014-2015) sonra yeşil alanlarda iyileştirme çalışmaları yapılmıştır. Zira mevcut haliyle yeşil alanların bakımsız ve giderek artan ihtiyaçlara cevap veremeyecek durumda olduğu ortaya çıkmışır. Bu noktadan hareketle mevcut yeşil alanların tekrar gözden geçirilerek işlevsel açıdan kullanım olanaklarının artırılması, bitkisel tasarım ve ekolojik (özellikle toprak) özellikleri açısından irdelenip iyileştirilmesi, kent halkına etkili bir kullanım sunmak üzere neler yapılabileceği konusunda öneriler getirilmiştir.
\end{abstract}

Anahtar kelimeler: Atatürk Köşkü ormanı, Boztepe ormanı, Kentsel yeşil alanlar, Lütfi Göktaş parkı, Peyzaj, Silvikültür

\begin{abstract}
In this study where urban green areas are evaluated in terms of landscape, ecology and silvicultural aspects; three urban green areas have been determined to be Atatürk Mansion Forest, Lütfi Göktaş Park (Ecopark) and Boztepe Forest located in the city center of Trabzon. Stand characteristics, ecological and landscape properties of these areas were examined. Sample areas representing the research areas were selected and a total of 10 soil pits (46 soil samples) and 9 stand profiles were taken in these areas. According to the data obtained, features such as the usage patterns, functionality and adequacy of green areas were evaluated. In the result of the study; all three areas had high clay content in terms of soil. It was determined that Atatürk Mansion and Boztepe Forest is limited in terms of plant species, while it is more in Lütfi Göktaş Park. It is understood that the tree species selection at the facility stage in all three areas does not fully comply with the habitat characteristics, and as a result, drying in plants occurs. For this reason, improvement studies were carried out in green areas after the date of the study (2014-2015). Because, in its current state, it has been revealed that green areas are neglected and unable to meet the increasing needs. From this point of view, suggestions have been made on what can be made in order to increase the usage possibilities in functional terms, to examine and improve them in terms of vegetative design and ecological (especially soil) features, and to offer effective use of the people in the city center.
\end{abstract}

Keywords: Atatürk Pavilion forest, Boztepe forest, Urban green areas, Lütfi Göktaş park, Landscape, Silviculture

\footnotetext{
*c Nebahat YILDIRIM; nebahat.yildirim@ktu.edu.tr, Tel: (0539)448 36 78, orcid.org/0000-0002-1795-050X

${ }^{\mathrm{a}}$ orcid.org/0000-0003-4408-1327 $\quad{ }^{\mathrm{b}}$ orcid.org/0000-0001-5394-5049
} 


\section{Giriş}

Aşırı nüfus artışı, göç, nükleer felâketler, kentlerin kontrolsüz büyümesi, yağmur ormanlarının giderek yok olması, asit yağmurları, sera etkisi, ozon tabakasının delinmesi gibi konular tüm insanlığın ortak kaygıları haline gelmiştir. Bu olumsuz etkiler, insanların yeşil alanlara olan ihtiyacını daha da ön plana çıkarmaktadır (Turna vd., 2017).

Kentsel yeşil alanlar, kent mekânı içinde fiziksel ve sosyal çevrenin niteliğini belirleyen, eğitimsel, kültürel ve rekreasyon amaçlı kullanımlara olanak tanıyan ve toplumun tüm bireylerinin kullanımına açık olan kamu mekânlarıdır (Yuen, 1996). Uygarlık tarihinin başlangıç noktası olarak kabul edilen kentsel mekânlar, insanların toplu yaşama içgüdüleri veya sosyalleşme eğilimlerinin ortaya koyduğu bir yaşam biçimi ve mekânı olarak karşımıza çıkmaktadır (Ceylan, 2007; Turna, 2017). Doğal hayatın destek sisteminin önemli bir elementi olan yeşil alanlar, aynı zamanda kentsel yaşamın sürdürülebilir olmasında da oldukça etkin rol oynarlar (Kuchelmeister, 2000). Kent halkına serbest zamanlarını değerlendirme yönünde sosyal ve psikolojik yararlar sağlayan yeşil alanlar, kent sosyal hayatında yaşam kalitesini arttırma yönünden stratejik öneme sahiptirler (Kurdoğlu ve Pirselimoğlu, 2011).

Yaşamı, fiziksel ve psikolojik olarak daha rahat k1lmak ve ihtiyaçlara daha uygun ortamlar oluşturmak için, kullanıcıların fiziksel, fizyolojik, psikolojik ve sosyal yapısından kaynaklanan ihtiyaçlarını önceden kestirmek ve açık mekanlardan oluşan çevreyi bu ihtiyaçlara göre şekillendirmek gereklidir (Aksoy, 2008). Bir kentte var olan mimari yapılar, yeşil alanlar ve bunların birbirleriyle olan ilişkileri ve bütünlüğü kente gerek estetik, gerekse fonksiyonel anlamda katk1 sağlayan, değer katan ve kente kimlik kazandıran önemli kentsel parçalardır. Kentsel karakterlerin oluşmasında da bu doğal ve kültürel öğeler birlikte rol oynamaktadır. İnsanlar açısından bir kentin yaşam kalitesini arttırmak için, bu iki öğe planlamanın her aşamasında bütünsel yaklaşımla ele alınmalıdır (Çakar, 2012). Yeşil alanlar, insan ile doğa arasındaki bozulan ilişkiyi dengelemede ve kentsel yaşam koşullarının iyileştirilmesinde önemli bir konuma sahip olduklarından gelişmiş ülkelerde yeşil alanların nitelik ve nicelikleri, medeniyetin ve yaşam kalitesinin bir göstergesi olarak kabul edilmektedir. Bu kapsamda pek çok gelişmiş ülke, insanların fiziksel ve zihinsel ihtiyaçlarını göz önünde bulundurarak insan yaşamı için uygun kent mekânı veya ekolojisini planlama ve oluşturma çabasına yönelmektedirler (Gül ve Küçük, 2001).

Trabzon kent merkezinde bilinçsiz yapılaşma ve kontrolsüz/plansız büyüme ile yeşil alanların giderek azalması, fiziksel ve ekolojik çevre sorunlarının ortaya çıkmasına sebep olmaktadır. İnsan yaşamında büyük öneme sahip olan yeşil alanlar betonlaşmaya dayalı büyüme sonucu tahrip edilmektedir. Çarpık kentleşmenin oluşturduğu olumsuzlukları iyileştirmek ve yaşam kalitesini yükseltmek giderek güçleşmekte olup uzun y1llar alacağ 1 açıktır. $\mathrm{Bu}$ nedenle mevcut dokuyu koruyarak imar planlarının yapılması, yeniden tesis edilecek ve tahrip edilmiş alanların amaca ve ortam koşullarına uygun bitki türleri ile bitkilendirilmesi yanında, peyzaj ve silvikültürel bakım çalışmalarının düzenli olarak yapılması gerekmektedir. Bu sayede kentsel yeşil alanların sürdürülebilirliği ve fonksiyonel olması sağlanır. Tüm Türkiye'de olduğu gibi Trabzon'da da mevcut yeşil alanların korunması, bakımı ve yeni yeşil alanların tesisine yönelik çeşitli çalışmalar yapılmaktadır. 2009 yılı verilerine göre Trabzon'da kent genelinde aktif yeşil alan 2 milyon 60 bin $\mathrm{m}^{2}$ ye ulaşırken, kişi başına düşen yeşil alan miktarı ise $8.59 \mathrm{~m}^{2}$ ye çıkarılmıştır. 2009 yılından bugüne kadar 22 adet park ve dinlenme alanı tesis ederek kente kazandıran Belediye, imar planında park ve yeşil alan olarak ayrılan yerlerde de park yapımını sürdürmektedir (URL-1,2015).

Trabzon kentinde yapılan bu çalışmanın amacı; belirlenen kentsel yeşil alanların işlevleri ve önemi konusunu vurgulamak, yeşil alanların ekoloji, peyzaj ve silvikültürel yönden değerlendirilerek gereksinimleri ve sorunlarının ortaya konulmasıdır.

\section{Materyal ve metod}

Kentsel yeşil alanların seçiminde büyüklük ve yerel halkın kullanım yoğunluğu esas alınmıştır. Trabzon ili Ortahisar İlçe sınırları içerisinde yer alan 1930'lu y1llarda oluşturulan Atatürk Köşkü Ormanı, 1995 yılında tesis edilen Lütfi Göktaş Park1 ve 1938 y1lında fidan dikim ile oluşturulan Boztepe Ormanı seçilmiştir. Çalışma 2014-2015 yılları arasında yürütülmüş olup, Lütfi Göktaş Parkı şu an gerek tür gerekse fonksiyonel özellikleri bakımından Ekopark olarak değiştirilmiştir. Atatürk Köşkü Ormanında 20182019 yıllarında meydana gelen böcek kaynaklı kurumlardan sonra "Atatürk Köşkü Orman Koruma ve Rehabilitasyon Projesi" kapsamında bazı değişikliklere gidilmiştir. Böylelikle Ekopark ve Atatürk Köşkü Ormanının önceki durumları 
esas alınmıştır. Örnek alanların coğrafi konumları

Şekil 1'de verilmiştir.

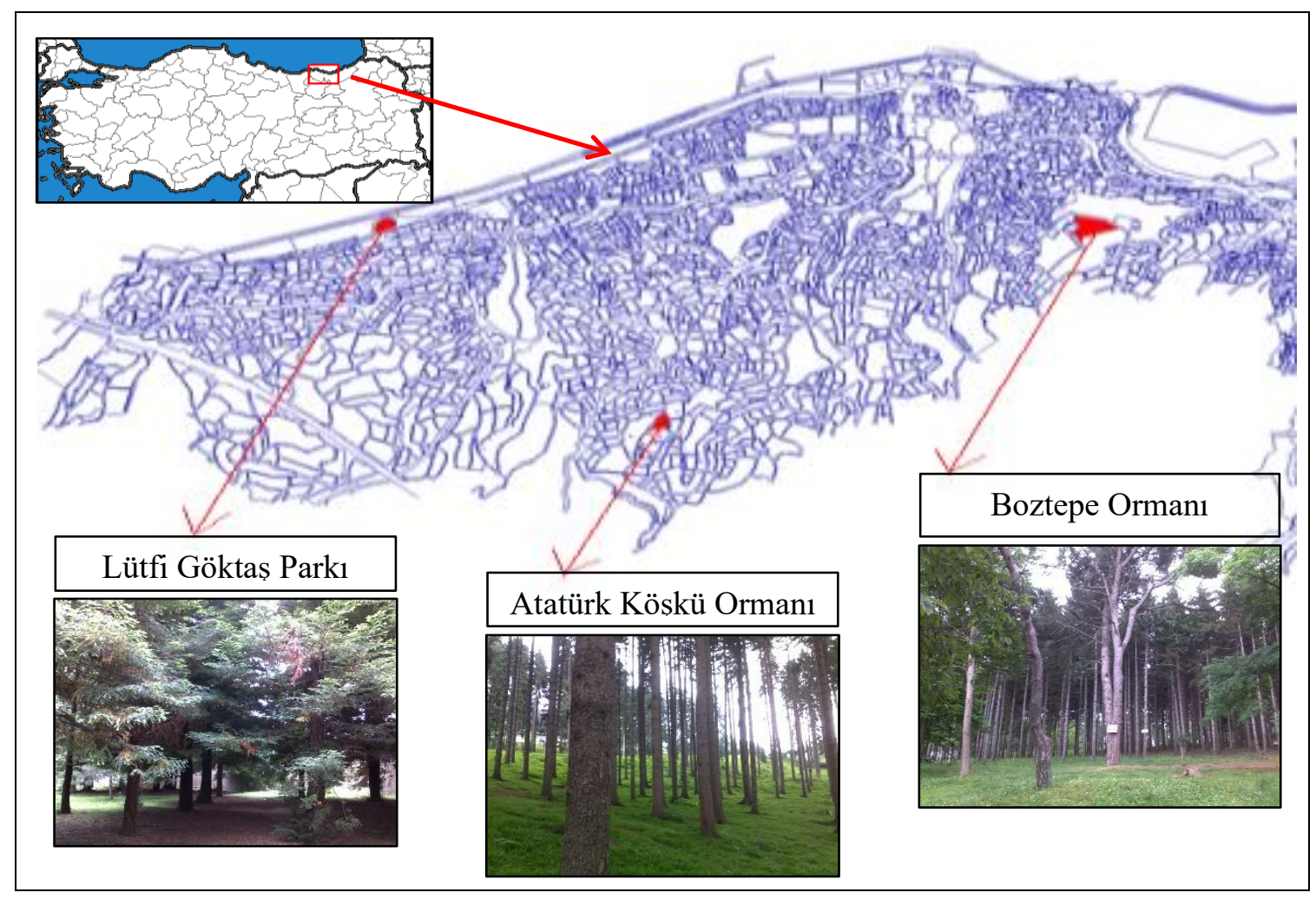

Şekil 1. Çalışmaya konu olan örnek alanların coğrafi konumları

Araştırma alanlarına ilişsin geçmişte konu ile ilgili kişi ve kuruluşların hazırladığı çalışmalar ve güncel veriler Trabzon Büyükşsehir Belediyesi Park ve Bahçeler Müdürlügü'nden temin edilmiş ve incelenmiştir. Meşcere profilleri için örnek alan içerisine giren ağaçlar tek tek incelenerek özellikleri (koordinat, tür, dip kütük $\left(\mathrm{d}_{0,30}\right)$ çap1 $(\mathrm{cm})$, göğüs $\left(\mathrm{d}_{1,30}\right)$ çap1 $(\mathrm{cm})$, boy $(\mathrm{m})$, dal uzunlukları, yaş dal yüksekliği) belirlenerek, boyutları $20 \mathrm{~m}$ x $20 \mathrm{~m}$ olacak şekilde $400 \mathrm{~m}^{2}$ 'lik ve $30 \mathrm{~m}$ x20 m boyutlarında $600 \mathrm{~m}^{2}$ lik olmak üzere Atatürk Köşkü ve Boztepe Ormanında 4'er adet ve Lütfi Göktaş Parkında ise 1 adet olmak üzere toplamda 9 adet meşcere profilleri alınmıştır. Örnek alanların toprak özelliklerinin belirlenmesi amacıyla; Atatürk Köşkü Ormanından ve Lütfi Göktaş Parkından 3'er adet ve Boztepe Ormanından ise 4 adet olmak üzere toplamda 10 adet toprak profili Çepel (1988)'e göre açılmıştır. Atatürk Köşkü Ormanı ve Boztepe Ormanında tüm profillerde 0-10, 10-30, 30-60, 60-100 cm derinlik kademelerinden toprak örnek alımı gerçekleştirilirken Lütfi Göktaş Parkında 0-10 ve 10-30 cm derinlik kademelerinde toprak örnekleri alınmıştır. Alınan toprak örneklerinin analizleri laboratuvar ortamında yapılmıştır.
Çalışma alanlarının peyzaj özelliklerini belirleyebilmek amaciyla üç alanda incelemeler ve ölçümler yapılmıştır. Örnek alanlarda bulunan bitkilerin görsel özellikleri (çizgi, doku, renk) bitkilerin ekolojik katkıları ve alanların kullanım özellikleri belirlenmiştir. Elde edilen bütün veriler, her üç alanın mevcut durumlarını, kullanımlarını ve yeterliliklerini belirlemek amacıyla oluşturulan peyzaj değerlendirmesi kimlik kartlarına yerleştirilmiştir (Tablo 1). Kimlik kartlarına, alanlarda olan veya olması gereken (görsel özellik, ekolojik özellik ve alan kullanım özelliği) öğeler işlenmiş ve değerlendirme yapılmıştır. Değerlendirmede alanların mevcut durumları ve belirlenen kriterlere uygunluğu " $\sqrt{ }$ " işareti ile gösterilmiştir.

\section{Bulgular ve tartışma}

\subsection{Atatürk köşkü ormanına ilişkin bulgular ve tartı̧̧ma}

Atatürk Köşkü Ormanı, Trabzon'un 7 km güney batısında, Soğuksu mahallesinde yer alan yaklaşık olarak 2.5 ha'lık bir alana sahiptir. Çalışma alanı içerisinde yapılan incelemelerde dikim yoluyla tesis edilen türlerin mevcut durumu (canl1-ölü vb.) ile kapalılığı belirlenmiştir. Yapılan tespitler 
sonucunda; Picea orientalis (L.) Link türünün; 1034 bireyi canlı (\%94.5) iken $60(\% 5.5)$ bireyi kuru, Pinus sylvestris L. türünün; 141 (\%95.3) bireyi canlı iken 7 (\%4.7) bireyi kuru, Sequoia sempervirens (D. Don) Endl. türünün 40 (\%97.6) bireyi canlı iken 1 (\% 2.4) bireyi kuru ve Ulmus minor Mill. türünden ise $1(\% 100)$ adet canlı birey mevcuttur. Toplamda 1216 (\%94.7) tür canl1, 68 (\%5.3) tür ise hastalık ve diğer sebeplerden dolayı kurumuştur. Araştırma alanında belirlenen toplam 1284 ağacin 1094'ü doğu ladini (Picea orientalis) ağacıdır. Yani çalışma alanındaki ağaçların \% 85.2'sini doğu ladini ağaçları oluşturmaktadır. Buna göre doğu ladini hâkimiyetinde karışık orman niteliğinde olan alan tamamen iğne yapraklı türlerden oluşmaktadır.

2015 yılı verilerinden sonra aynı alanda böcek başta olmak üzere çeşitli nedenlerle oluşan aşırı kurumaların olduğu görülmüştür. Bundan dolayı 2018 yılında KTÜ Orman Fakültesi öğretim üyeleri tarafindan hazırlanan raporda alanda mevcut toplam 1041 ağacın 326's1 (\%31) Oniki dişli çam kabuk böceği (Ips sexdentatus (Boern)), zararı ile tamamen kuruduğu belirlenmiştir. Kuruyan ağaçların 286'sı (\%87.7) doğu ladini, 40 adedinin (\%12.3) sarıçam olduğunu raporlanmıştır (Anonim, 2018).

Alınan 3adet meşcere profili ile alanın yükseltisi 312-360 m arasında değişmektedir. Hâkim bakı kuzey, eğimi \%23.9-\%30.8 arasındadır. Alanlardaki doğu ladininde minimum ve maksimum boy $(\mathrm{m})$ değerleri sirasiyla 17.3-37.2, minimum ve maksimum çap $(\mathrm{cm})$ değerleri ise 1846 olarak tespit edilmiştir. Sarıçamlarda minimum ve maksimum boy (m) değerleri 9.8-24.5 iken minimum ve maksimum çap $(\mathrm{cm})$ değerleri 19-42 cm'dir. Sekoya türünde minimum boy $5.1 \mathrm{~m}$, maksimum boy $13 \mathrm{~m}$, minimum çap $12 \mathrm{~cm}$, maksimum çap $32 \mathrm{~cm}$ olarak ölçülmüştür. Toprak özelliklerini belirlemek amacıyla farklı ağaç türlerinin yoğun olduğu alanlarda 3 adet toprak profili alınmış ve analiz sonuçları Tablo 2'de verilmiştir.

Tablo 1. Peyzaj değerlendirmesi kimlik kartı

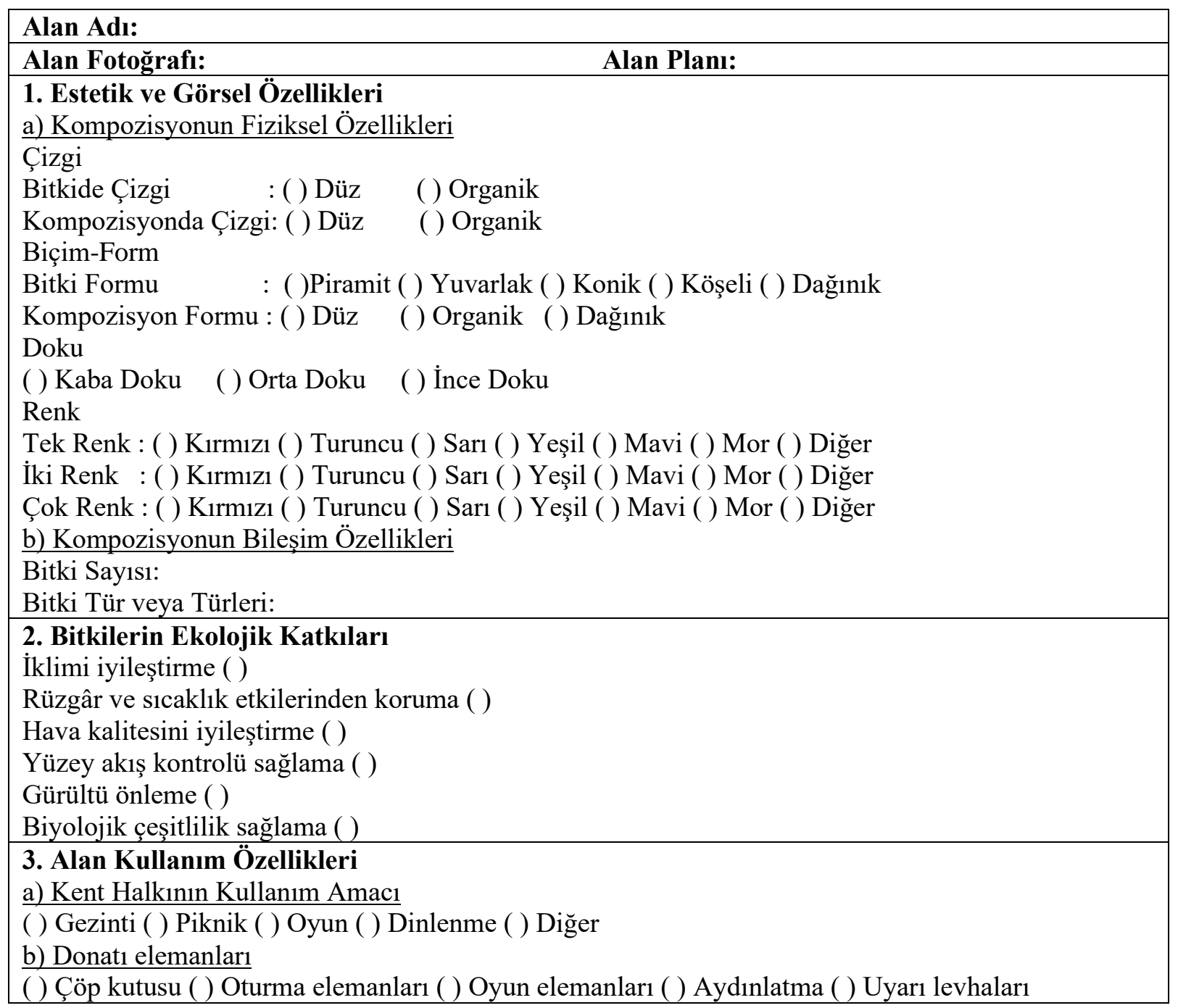


Tablo 2. Atatürk Köşkü Ormanında ağaç türüne göre bazı fiziksel ve kimyasal toprak özellikleri

\begin{tabular}{|c|c|c|c|c|c|c|c|c|}
\hline Ağaç Türü & $\begin{array}{c}\text { Derinlik } \\
(\mathbf{c m})\end{array}$ & $\begin{array}{c}\text { Kum } \\
(\%)\end{array}$ & $\begin{array}{l}\text { Toz } \\
(\%)\end{array}$ & $\begin{array}{l}\text { Kil } \\
(\%)\end{array}$ & $\begin{array}{c}\text { Toprak } \\
\text { Türü }\end{array}$ & $\begin{array}{c}\text { pH } \\
\text { (suda) }\end{array}$ & $\begin{array}{c}\mathbf{E C} \\
(\mu \mathrm{S} / \mathbf{c m})\end{array}$ & $\begin{array}{l}\text { OM } \\
(\%)\end{array}$ \\
\hline \multirow{4}{*}{ Picea orientalis } & $0-10$ & 29.97 & 22.10 & 47.9 & Ağır Kil & 5.04 & 85.77 & 1.31 \\
\hline & $10-30$ & 35.85 & 23.05 & 41.05 & Balçıklı Kil & 4.96 & 81.95 & 1.86 \\
\hline & $30-60$ & 32.78 & 23.15 & 44.05 & Balçıklı Kil & 4.98 & 91.88 & 1.40 \\
\hline & $60-100$ & 32.91 & 22.58 & 44.48 & Balçıklı Kil & 5.00 & 83.86 & 1.58 \\
\hline \multirow{4}{*}{ Pinus sylvestris } & $0-10$ & 36.1 & 21.9 & 41.9 & Balçıklı Kil & 5.00 & 65.9 & 2.22 \\
\hline & $10-30$ & 35.6 & 24.2 & 40.2 & Balçıklı Kil & 4.92 & 98 & 1.49 \\
\hline & $30-60$ & 40.2 & 24.0 & 35.7 & Balçıklı Kil & 5.09 & 63.3 & 1.12 \\
\hline & $60-100$ & 40.3 & 21.7 & 38.0 & Balçıklı Kil & 4.86 & 98.3 & 2.07 \\
\hline \multirow{4}{*}{$\begin{array}{c}\text { Sequoia } \\
\text { sempervirens }\end{array}$} & $0-10$ & 42.1 & 26.0 & 31.9 & Balçıklı Kil & 5.51 & 109.9 & 5.63 \\
\hline & $10-30$ & 36.2 & 25.8 & 37.9 & Balçıklı Kil & 5.4 & 170.4 & 2.54 \\
\hline & $30-60$ & 38.2 & 21.7 & 40.1 & Balçıklı Kil & 4.85 & 58.1 & 1.44 \\
\hline & $60-100$ & 36.5 & 23.6 & 39.9 & Balçıklı Kil & 4.87 & 48.5 & 1.29 \\
\hline
\end{tabular}

Tablo 2 verilerine göre toprak türünün genel olarak balçıklı kil olduğu görülmektedir. Alanda hâkim ağaç türünün doğu ladini olduğu düşünüldüğünde toprak türünün çok uygun olmadığ1 anlaşılmaktadır. Nitekim Yılmaz (2000), yapmış olduğu bir araştırmada doğu ladininin hafif toprak sevdiğini belirtmiştir. Çalışma alanına ait verilerde üst toprakta (0-10) en yükssek kum içeriği Sahil sekoyası alanında, en düşük kum değeri Doğu ladini alanında ölçülmüştür. Bunun olası nedenleri arasında Sahil sekoyası alanında toprağın daha gevşek bir yapıya sahip olduğu ve kapalılık oranı düşük olduğu için toprak yüzeyine daha fazla yağış sularının ulaşması ve bu nedenle kil fraksiyonunu yıkayarak toprak kesitinde aşağ 1 derinliklere taşımasının etkisi olduğu düşünülmektedir. Doğu ladini ve sarıçam alanları bu durumun tersi yönde bir eğilim göstermektedir. Bu alanda orman bakımı tedbirleri (aralama) zamanında yapılmamış, aşırı insan kullanımına maruz kalmıştır. Bunun bir sonucu olarak toprağın sıkışmış ve kapalılığın yüksek olması nedeniyle üst toprağa gelen yağışların yüzeysel akışa geçmesi daha az kil yıkanmasına sebep olabilmektedir. $\mathrm{Bu}$ da üst toprakta düşük olan kum oranının derinlikte artmasına, yüksek olan kil oranının ise derinlikte azalmasına neden olmaktadir. Ayrıca bu alanda derinlik kademelerinde toz miktarları arasında anlamlı bir değişikliğin olmamasında kum ve kil içeriklerinin etkisi olduğu sanılmaktadır. Benzer şekilde Anonim (2018), deki raporda da kil oranının fazla olmasından dolayı toprak süzekliği düşük bulunmuştur. Raporda buna ek olarak, alanın önceden mesire yeri olarak kullanılması ve buna bağlı toprakta meydana gelen sıkışma nedeniyle de ağaç köklerinin gelişimi ve toprağın su depolama kapasitesinin olumsuz etkilendiği vurgulanmıştır.
Toprakların $\mathrm{pH}$ değerinin 4.85-5.5 arasında olması asidik özellikte olduğunu göstermektedir. Derinlik kademeleri açısından incelendiğinde toprak tepkimesinin genel olarak derinlik arttıkça azaldığı görülmektedir. $\mathrm{Bu}$ durum toprağın sıkışı olmasından kaynaklanabilir. Çünkü sıkışı topraklarda havalanma kabiliyeti düşüktür ve yağış suları yüzeysel akışa geçer ve topraktaki bazlar yağmur sularıyla yıkanarak uzaklaşır (Akalan, 1987). Toprak örnekleri tuzluluk açısından incelendiğinde topraklar tuzsuz karakterdedir. Ağaç türü ve derinlik kademelerine göre toprak organik madde miktarı genel olarak üst toprak, alt toprağa nazaran daha yüksektir. Bu beklenen bir durumdur. Çünkü derinlik arttıkça toprak organik madde miktarı azalmaktadır (Zengin, 2010; Kırış, 2009).

Atatürk Köşkü Ormanı peyzaj değerlendirme kimlik kartı verilerinden hareketle değerlendirdiğimizde alanın bitkisel kompozisyonu, estetik değeri ve kullanım çeşitliliği açısından zayıf özellikler gösterdiği ortaya çıkmıştır. Zira alana dikilen türlerin bakımlarının zamanında yapılmadığı, estetik değer fonksiyonlu olarak planlanmadığı anlaşılmaktadır. Dolayısıyla ormanda görsel amaçlı herhangi bir bitkilendirme ve alan kullanımına yönelik tasarım bulunmamaktadır. Bitkisel elemanların vurgu yaratmak, perdeleme yapmak, üst örtü olarak kullanmak, mekân hissi uyandırmak, alana üçüncü boyut etkisini katmak ya da sadece estetik kaygılarla renk etkisinden yararlanmak gibi birçok kullanım amaçları vardır (Sakıcı vd., 2013; Vural, 2020). Bitkilerin durağan olmaması, çiçeklerin büyümesi ve olgunlaşması, özellikle geniş yapraklı türlerin sonbaharda yaprakların dökülmesi insanlara günlerin hızla geçtiğini göstergesi olup monotonluğu engellemektedir (Smardon, 1990; 
Mcdowell, 1997; Sakıc1, 2009). Bitkilerin bu ve benzeri birçok fonksiyonu olmasına rağmen alandaki özellikle doğu ladini ağaçları sıralar halinde dikilerek tekdüzelik oluşturulmuştur. Sahil sekoyası görsel güzelliği yüksek olan, soliter kullanılması gereken bir tür olmasına rağmen alana grup halinde getirilmiştir. Ayrıca alandaki türlerin sadece iğne yapraklı türlerden seçildiği, geniş yapraklı türlere yer verilmediği, herhangi bir ağaççık ve çalı türlerinin olmadığı da görülmektedir. Bu durum biryandan kentsel yeşil alanın her türlü hastalık vb. zararlılara karşı zayıf kalmasına diğer yandan da monoton bir görünümde olmasına neden olmuştur. Nitekim bakımsızlık yanında yaşlanma ve toprak sıkışmaları gibi nedenlerle ormanda kurumalar görülmeye başlamıştır. 2017-2018 yıllarındaki aşırı kurumalardan sonra 2018 y1linda arazi incelemelerine dayanılarak hazırlanan rapor doğrultusunda alana, Gürgen, kayın, ıhlamur, karaağaç, akçaağaç, sedir gibi doğal türler dikilmiştir. Böylece hem hastalıklara dayanıklı hem de monoton görünümün ortadan kalkmasına yönelik karışık meşcere tesisine gidilmiştir.

Kentsel parklar, insanların günlük kullanım içinde kolaylıkla erişebilecekleri yerlerde bulunmakta ve yürüyüş, koşu, dış mekânda oturma, piknik yapma, oyun ve benzeri bireysel ya da grup eylemlerine olanak sağlamaktadır (Oğuz, 1998). Trabzon kenti içerisinde yer alan Atatürk Köşkü Ormanı gerek yerli gerekse yabancı turistler tarafindan ziyaret edilmekte ve dinlenmek, piknik yapmak ya da temiz hava almak için yoğun olarak kullanılmaktadır. Bununla birlikte alan içerisinde herhangi bir yürüyüş yolu, oturma bankları, seyir terasları, çeşme, otopark, WC, çöp kovası, özel dinlenme alanları, oyun alanları, uyarı ve yönlendirme levhası gibi donatı elamanları da bulunmamaktadır.

\subsection{Lütfi Göktaş parkına ilişkin bulgular ve tartı̧̧ma}

Lütfi Göktaş Parkı, Trabzon merkez sınırları içerisindeki 2 No'lu Beşirli Mahallesinde yer almakta olup yaklaşık olarak 0.18ha'lık bir alana sahiptir. Çalışma alanı dolgu alanı olup taşıma topraklarla yapılmıştır. Çalışmanın yapıldı̆̆ 1 tarihten sonra 2016 y1lında Ekopark'a dönüştürülmüştür. Alandaki ağaçlar dikim yoluyla tesis edilmiş olup park halkının kullanımına açık bir alandır. Çalışma alanında 23 farklı bitki türü tespit edilmiştir. Böylelikle alanda en fazla bulunan türden en az bulunan türe göre siraladığımızda; Sequoia sempervirens (D.Don) Endl. (67 adet), Picea abies (L.) Karst. (60), Pinus pinaster Ait. (56), Platanus orientalis L. (10), Eucalyptus camaldulensis Dehnh. (9), Pinus nigra Jf Arnold (7), Tilia tomentosa Moench (6), Cupressus sempervirens L. var. horizontalis (Mill.) Gord. (5), Laurus nobilis L. (5), Pinus sylvestris L. (4), Cedrus libani A. Rich. (4), Fraxinus excelsior L. (4), Betula pendula Roth. (4), Magnolia grandiflora L. (3), Phoneix dactiylifera L. (3), Biota orientalis L. Endl. (2), Morus alba L. (2), Aesculus hippocastanum L. (2), Cryptomeria japonica D.Don (2), Eriobotrya japonica Lindl. (2), Pinus wallichiana AB Jackson (1), Malus floribunda Sieb. ex Van Houtte (1) ve Gleditsia triacanthos L. (1) olmak üzere ve toplamda 260 adet ağaç ve ağaççık türü alanda bulunmaktadır. Alan yeterli 1 şık aldığından park içerisinde alt tabaka (otsu diri örtü) mevcut olup türlerin sağlıklı olduğu gözlenmiştir.

Lütfi Göktaş Parkının meşcere profilleri ve bunların çeşitli silvikültürel özelliklerini belirlemek amaciyla 1 adet meşcere profili alınmıştır. Örnek alan deniz seviyesinde, hâkim bak1 güney, eğimi \%3.5 ve kapalılık oranı 0.70.8 'dir. Örnek alanda çoğunlukla sahil sekoyası ağaçları olmakla minimum ve maksimum boy değerleri 12.3-23.5 m, minimum ve maksimum çap değerleri ise $6-46 \mathrm{~cm}$ olarak ölçülmüsstür. Toprak özelliklerini belirlemek amaciyla 3 adet toprak profil örneği alınmıştır. Yapılan analiz sonuçları ise Tablo 3'de verilmiştir.

Tablo 3. Lütfi Göktaş Parkının ağaç türüne göre bazı fiziksel ve kimyasal toprak özellikleri

\begin{tabular}{lllllllll}
\hline \multicolumn{1}{c}{ Ăgaç Türü } & $\begin{array}{c}\text { Derinlik } \\
(\mathbf{c m})\end{array}$ & $\begin{array}{c}\text { Kum } \\
(\boldsymbol{\%})\end{array}$ & $\begin{array}{c}\text { Toz } \\
(\boldsymbol{\%})\end{array}$ & $\begin{array}{c}\text { Kil } \\
(\boldsymbol{\%})\end{array}$ & $\begin{array}{c}\text { Toprak } \\
\text { Türü }\end{array}$ & $\begin{array}{c}\mathbf{p H} \\
(\mathbf{s u d a})\end{array}$ & $\begin{array}{c}\text { EC } \\
(\boldsymbol{\mu} \mathbf{S} / \mathbf{c m})\end{array}$ & $\begin{array}{c}\text { OM } \\
(\boldsymbol{\%})\end{array}$ \\
\hline Sequoia & $0-10$ & 59.0 & 11.9 & 29.1 & Kumlu Kil & 7.61 & 177.8 & 0.06 \\
sempervirens & $10-30$ & 68.2 & 5.2 & 26.6 & Kumlu Kil & 7.83 & 142.5 & 0.72 \\
\hline Picea abies & $0-10$ & 47.5 & 14.2 & 38.3 & Balçılı Kil & 7.29 & 232.6 & 2.89 \\
& $10-30$ & 62.1 & 9.4 & 28.5 & Kumlu Kil & 7.67 & 160.4 & 1.51 \\
\hline Karış1k yapraklılar & $0-10$ & 49.2 & 11.6 & 39.2 & Balç1klı Kil & 7.54 & 140.6 & 1.33 \\
& $10-30$ & 49.3 & 11.6 & 39.2 & Balçılı Kil & 7.38 & 226.6 & 1.89 \\
\hline
\end{tabular}


Lütfi Göktaş Parkından alınan toprak örneklerinde kum değerlerinin, toz ve kil değerlerine göre daha yüksek olduğu görülmektedir. Alanın dolgu alanı olması ve toprak içerisindeki taş oranının yüksek olmasından dolayı kum değeri yüksek çıkmıştır. Ayrıca derinlik kademeleri arttıkça kum oranı artmış kil ve toz oranlarının da azaldığ görülmektedir. Bu durum topraktaki kilin ve tozun yıkanmadığını göstermektedir. Toprakların $\mathrm{pH}$ değerlerinin 7.29-7.83 seviyesinde olmas1 toprakların hafif alkali özelliğe sahip olduğunu göstermektedir. Bunun nedeni alanın dolgu topraklarından oluşması ve toprakta herhangi bir yıkanmanın söz konusu olmamasıdır. EC bakımından topraklar tuzsuz karakterdedir. Toprağın üst kısmı organik maddece en zengin olan yeridir. Fakat Lütfi Göktaş Parkı'nda böyle bir durum söz konusu değildir. Bunun nedeni toprakların taşıma topraklardan oluşması ve alanın taşlık olmasından kaynaklandığg söylenebilir.

Lütfi Göktaş Parkı için oluşturulmuş peyzaj değerlendirmesi kimlik kartında bitkilerin görsel özellikleri, ekolojik özellikleri ve alanların kullanım özelliklerine ilişkin değerlendirmeler yapılmıştır. Kent parklarında bitkiler kullanılarak mikro klima, havayı iyileştirme, tozları filtre etme ve gürültüyü azaltma gibi işlevleri yanında, insanın bedensel ve ruhsal yapisinda olumlu etkileri bulunur (Aksoy, 2001; Elinç, 2011; Gülpınar Sekban vd., 2018). Buna göre verilen plan ve verileri değerlendirdiğimizde alan yol kenarında bulunduğundan kent içindeki havayı temizleme, gürültüyü önleme fonksiyonlarından dolayı önemli bir yere sahiptir. Bitkiler parkların tasarımına veya biçimlenmesine tüm özellikleri ile katkı sağlayan çok önemli elemanlardır (Tarakcı Eren ve Var, 2016). Kentsel habitatların yüksek oranda heterojen bir yapıya sahip olması kentsel floranın zengin olmasının nedenlerinden sayılmaktadır (Kowarik, 2011). Alan içinde bulundurduğu farklı türler nedeniyle de biyolojik çeşitliliğe katkı sağlamaktadır. Alan küçük olduğu için farklı kullanım çeşitliliği yoktur. İnsanlar tarafından da çok fazla ziyaret edilmemektedir. Gelenlerde sadece yürüyüş yapıp gitmekteydiler. Ancak alan Ekopark'a dönüşümünde birçok kullanım alanları düzenlenmiş ve şu an Ekopark'ta yoğun bir kullanım söz konusu olmuştur. Öncesinde alanın sosyal aktivite için değil, kent içerisinde görsel etkisi yüksek olan bir yeşil alan olarak tesis edildiğini söyleyebiliriz. Lütfi Göktaş Park1, küçük bir alan olmasına rağmen bitki seçimindeki çeşitlilikten dolayı görsel doyum sağlayabilen, dikkat çekici bir yeşil alandır. Alan bu özelliğiyle ön plana çıkmaktadır. Geniş yapraklı ve iğne yapraklı türlerin karışım halinde kullanılmış olması, alanın görsel kalitesini arttırmaktadır (Acar ve Sakıc1, 2008). Alanda bulunan bitkilerden olan sahil sekoyası ve doğu çınarı türleri sıralar halinde düzenli olarak dikilmişken, diğer türler düzensiz olarak dikilmiştir. Görsel etkisi yüksek olan türlerin ise alanda soliter olarak kullanıldı ğ görülmektedir (Magnolia grandiflora gibi). Ayrıca alanda, yeşil dışında çeşitli renk ve formlarda bitkilerin kullanılmış olması alanı daha estetik bir hale getirmiştir.

\subsection{Boztepe ormanına ilişkin bulgular ve tartışma}

Trabzon'un $5 \mathrm{~km}$ doğusunda Boztepe Mahallesi'nde yer alan Boztepe Ormanı yaklaşık olarak 3.7 ha'lik bir alana sahiptir. Alan, Trabzon merkez sınırları içerisinde yer alan yeşil alanların büyük bir kısmını oluşturmaktadır

Çalışma alanı içerisinde 16 farklı ağaç ve ağaççık türü tespit edilmiş olup; Picea orientalis türünün toplam 1311 adet bireyinden 92adet ağaç kuru, Pinus pinea L. türünün toplam 267 adet bireyinden 19 adet ağaç kuru olduğu gözlenmemişti. Alana ait olan diğer türler ve sayıları; Fraxinus angustifolia Vahl. subsp. oxycarpa (Bieb. ex Willd) Franco \& Rocha Afonso (29), Pinus sylvestris L. (28), Robinia pseudoacacia L. (25), Populus tremula L. (16), Pinus pinaster Ait. (12), Acer negundo L. (9), Acer pseudoplatanus L. (4), Cryptomeria japonica D.Don.(4), Morus alba L.(2), Sequoia sempervirens (D.Don.) Endl. (1), Aesculus hippocastanum L. (1), Salix babylonica L. (1), Cerasus avium L. (1) ve Prunus domestica L. (1) olarak tespit edilmiştir. Boztepe Ormanındaki iğne yapraklı türlerde genel olarak doğal dal budanması iyi değildir. Işıksızlıktan kuruyan dallar ağaç üzerinde uzun süre kalabilmektedir. Özellikle doğu ladini ve fistık çamı türlerinde 1şıksızlıktan dolayı tepelerin alt kısmında kuru dallar diğer türlere göre daha fazladır ve ağaçların tepe kısımları gelişiminin de zayıf olduğu gözlemlenmiştir. Alanda gözlemlenen diğer olumsuz bir durum ise Boztepe Ormanının gezinti yeri ve piknik alanı olması nedeniyle alanda oluşan kirlilik ve toprakta oluşan sıkışmadır. Ayrıca meşcere altındaki toprağın halk tarafından zaman zaman süpürüldüğü de görülmüsştür. $\mathrm{Bu}$ da ağaçların gelişimini olumsuz yönde etkilemektedir. Ağaçlardan dökülen ibrelerin zamanla ayrışmakta ve toprağa karışarak onu besin bakımından zenginleştirdiği bilinmektedir. Toprağın süpürülüp ibrelerin uzaklaştırılması buradaki toprağın fakirleşmesine sebep olmaktadir.

Alandan toplamda 4 adet meşcere profili alınmış olup, örnek alanlardaki yükseltiler 214-241m 
arasında değişmektedir. Hâkim bakı kuzey, eğimi \%6.7- \%29.5 arasındadır. Meşcere yaşı 78'dir. Örnek alanlardaki doğu ladini ağaçlarının minimum ve maksimum boy değerleri 7.9 m-29.7 $\mathrm{m}$ iken, minimum ve maksimum çap değerleri 16$32 \mathrm{~cm}$ olarak tespit edilmiştir. Fistıkçamı ağaçlarının minimum ve maksimum boy değerler
6.3-20 m, minimum ve maksimum çap değerleri ise $17-47 \mathrm{~cm}$; Sarıçam ağaçlarının minimum ve maksimum boy değerler $14.6-26 \mathrm{~m}$, minimum ve maksimum çap değerleri ise $33-46 \mathrm{~cm}$ olarak ölçülmüştür. Alana ait toprak özellikleri Tablo 4'de verilmiştir.

Tablo 4. Boztepe Ormanının ağaç türüne göre bazı fiziksel ve kimyasal toprak özellikleri

\begin{tabular}{|c|c|c|c|c|c|c|c|c|}
\hline Ağaç Türü & $\begin{array}{c}\text { Derinlik } \\
(\mathbf{c m})\end{array}$ & $\underset{(\%)}{\text { Kum }}$ & $\begin{array}{l}\text { Toz } \\
(\%)\end{array}$ & $\begin{array}{l}\text { Kil } \\
(\%)\end{array}$ & $\begin{array}{c}\text { Toprak } \\
\text { Türü }\end{array}$ & $\begin{array}{c}\text { pH } \\
\text { (suda) }\end{array}$ & $\begin{array}{c}\text { EC } \\
(\mu \mathrm{S} / \mathrm{cm})\end{array}$ & $\begin{array}{l}\text { OM } \\
(\%)\end{array}$ \\
\hline \multirow{4}{*}{$\begin{array}{l}\text { Fraxinus angustifilia } \\
\text { subsp. oxycarpa }\end{array}$} & $0-10$ & 37.2 & 21.7 & 41.2 & Balçıklı Kil & 6.46 & 68.7 & 4.32 \\
\hline & $10-30$ & 29.9 & 20.3 & 49.7 & Ağır Kil & 6.37 & 69.2 & 1.98 \\
\hline & $30-60$ & 15.0 & 10.2 & 74.8 & Ağır Kil & 4.87 & 69.8 & 0.67 \\
\hline & $60-100$ & 12.5 & 8.0 & 79.5 & Ağır Kil & 5.19 & 29.7 & 0.42 \\
\hline \multirow{4}{*}{ Picea orientalis } & $0-10$ & 34.65 & 22.6 & 42.75 & Balçıklı Kil & 5.08 & 117.80 & 4.39 \\
\hline & $10-30$ & 38.95 & 16.2 & 44.9 & Balçıklı Kil & 4.79 & 118.80 & 1.60 \\
\hline & $30-60$ & 41.8 & 16.2 & 42 & Balçıklı Kil & 4.88 & 151.80 & 0.87 \\
\hline & $60-100$ & 26.05 & 13.15 & 60.75 & A ğır Kil & 4.76 & 153.35 & 0.42 \\
\hline \multirow{4}{*}{ Pinus pinea } & $0-10$ & 36.3 & 26.5 & 37.2 & Balçıklı Kil & 6.18 & 127.1 & 3.36 \\
\hline & $10-30$ & 36.7 & 26.3 & 37.0 & Balçıklı Kil & 5.56 & 121.1 & 2.42 \\
\hline & $30-60$ & 44.9 & 16.4 & 38.7 & Balçıklı Kil & 5.25 & 167.2 & 1.16 \\
\hline & $60-100$ & 46.9 & 14.3 & 38.9 & Balçıklı Kil & 5.3 & 157.6 & 0.82 \\
\hline \multirow{4}{*}{$\begin{array}{c}\text { Pinus sylvestris- } \\
\text { Robinia pseudoacacia }\end{array}$} & $0-10$ & 38.1 & 20.6 & 41.3 & Balçıklı Kil & 5.97 & 134.2 & 5.15 \\
\hline & $10-30$ & 46.5 & 19.3 & 34.3 & Balçıklı Kil & 6.34 & 112 & 2.51 \\
\hline & $30-60$ & 55.4 & 10.4 & 34.2 & Kumlu Kil & 5.36 & 259.7 & 0.62 \\
\hline & $60-100$ & 68.2 & 7.8 & 24.0 & $\begin{array}{c}\text { Kumlu Killi } \\
\text { Balçık }\end{array}$ & 5.28 & 315 & 0.27 \\
\hline
\end{tabular}

Çalışma alanına genel olarak bakıldığında kil oranının kum ve toz oranına göre her derinlik kademesinde yüksek olduğu görülmektedir (Tablo 4). Bunun nedeni alana daha önceden ağır killi toprağın dökülüp yayılmasıdır. Toprak $\mathrm{pH}$ bakımından 4.76-6.46 arasında asitli olup EC bakımindan tuzsuz karakterdedir. Derinlik kademeleri açısından incelendiğinde toprak tepkimesinin genel olarak derinlik arttıkça azaldığı görülmektedir. Bunun nedeninin toprağın sıkışık olmasından dolayı bazik katyonlar yıkanmadığ 1 için $\mathrm{pH}$ oranını düşürmektedir (Akalan, 1987). Toprak organik madde miktarı üst toprakta $(0-$ $10 \mathrm{~cm}$ ve $10-30 \mathrm{~cm})$, alt toprağa $(30-60 \mathrm{~cm}$ ve $60-$ $100 \mathrm{~cm}$ ) göre daha yüksektir. Kırış (2009), yaptığ çalışmada genelde üst topraktaki organik madde miktarını alt toprağa nazaran daha yüksek olduğunu belirtmiştir. Alt toprak derinlik kademelerinde ise birbirine yakın oranlar söz konusudur.

Boztepe Ormanı, kent içindeki konumu ve büyüklüğü açısından Trabzon için önemli bir yeşil alandır. Kent ormanına erişilebilirlik kentsel alanların foksiyonel kullanımı açısından önemli kriterlerden biridir (Turna, 2017). Kent merkezine yakınlığ olan bu alanda etrafinda yer alan kafe, park gibi mekânların varlığı nedeniyle tüm kentten kullanıcılara rastlanmaktadır. Boztepe Ormanını değerlendirdiğimizde büyük bir alan olmasına rağmen farklı kullanımlara olanak sağlayan mekânlar bulunmamaktadır. Mevcut kullanımlarda da estetik ve fonksiyonellik sağlanamamıştır. Bu doğrultuda bitkisel tasarım ve estetik değer açısından baktığımızda, alan zayıf özellikler göstermektedir. $\mathrm{Bu}$ bağlamda alanda bitkisel öğelerin kullanımının genel olarak başarılı olmadığını söylemek mümkündür. Alanda daha çok boylu ağaç gruplarına yer verilmiştir; yer örtücü ve çalılara yer verilmemiştir. Alanda genel olarak iğne yapraklı türler baskın olmakla birlikte yer yer geniş yapraklı türlere de yer verilmiştir. Bitkisel tasarımda iğne yapraklı türlerin yanında geniş yapraklı türlere yer verilmesi estetik değeri arttırmakla birlikte kentin ekolojik dengesine de katkı sağlamaktadır. Alanda bulunan iğne yapraklı türlerden doğu ladini ve fistıkçamı türleri grup halinde sıralar şeklinde dikilmiştir. Buda alanın sıkıcı görünmesine neden olmaktadır. Ayrıca alanda yeşil renk hâkim olmakla birlikte az da olsa farklı renklere de rastlanmıştır. Oysa çeşitli renklerde bitkilerin daha fazla kullanılması ile 
alanın dört mevsim yaşaması sağlanabilir (Sakıcı vd., 2013).

Boztepe Ormanı büyüyen kentleşme içerisinde kentin akciğeri konumundadır. Kent iklimini iyileştirip hava kalitesini arttırır (Dirik, 1991; Akbari vd., 1992; Aksoy, 2001). İnsanlar için ise kent yoğunluğundan kaçış noktasıdır. $\mathrm{Bu}$ doğrultuda kullanım olanakları açısından alana baktığımızda insanlar başta piknik olmak üzere, dinlenmek, eğlenmek ve yürüyüş yapmak için alanı kullanmaktadır. Fakat alan bu etkinlikler için yeterli olanağı sunamamaktadır. Çünkü alanda oturma mekanları, yürüyüş yolları, oyun alanı gibi farklı kullanımlar bulunmamaktadır. Bu nedenle farklı yaş gruplarına yeterli hizmet vermemektedir. Park alanında verilen hizmet kalitesinin yükseltilmesi ve tatmin seviyesinin arttırılması, park planlaması süreçlerine etki eden parametrelerin bu doğrultuda düzenlenmesi ve uygulanması ile mümkündür (Onsekiz ve Emür, 2008). Bunun yanında çalışma alanında donatı elemanlarının (çöp kovası, otuma bankları, uyarı ve yönlendirme levhaları, aydınlatma gibi) eksik olduğu gözlemlenmiştir.

\section{Sonuç ve öneriler}

Araştırma Atatürk Köşkü Ormanı, Boztepe Ormanı ve Lütfi Göktaş Parkı'nda gerçekleştirilmiştir. İncelenen bu alanların tür çeşitliliğgine bakıldığında Atatürk Köşkü Ormanındaki ağaçların \%85.2'lik büyük bir kısmı doğu ladini ağaçlarından az bir kısmı da sarıçam ve sahil sekoyası ağaçlarından oluşmaktadır. Boztepe Ormanının da \%76.5'lik bir oranla doğu ladini ağaçları oluşmaktadır. Bunun yanında fistıkçamı, sarıçam ve yalancı akasya türleri de az bir bölümü kaplamaktadır. Yani bu iki alana bakıldığında, alanların doğu ladini ağaçlarından oluştuğu sonucu ortaya çıkmaktadır. Lütfi Göktaş Parkı'nda ise genel anlamda baskın olarak sahil sekoyası, Avrupa ladini ve sahil çamı türleri bulunmakta olup diğer türler birbirine yakın oranlar göstermektedir.

Atatürk Köşkü Ormanı ve Boztepe Ormanının estetik özellikleri açısından, kent insanlarının ihtiyaçlarını karşılayacak nitelikte olmadığı tespit edilmiş olup bitkisel tasarım ve donatı olarak alanların yeniden tasarlanması ve planlanmasının gerektiği düşünülmektedir. Boztepe Ormanında kullanılan tür sayısı az olduğu gibi daha çok iğne yapraklı türler tercih edilmiş ve bitkilerin renk, form ve tekstür özelliklerinden yararlanılmamıştır. $\mathrm{Bu}$ doğrultuda yeniden yapilacak bitkisel tasarımlarda alanların tekdüzeliğini kırmak için farklı form ve renklerde bitkilere yer verilmelidir.
$\mathrm{Bu}$ anlamda kullanılacak farklı ağaç, ağaççık ve çalı türleri ile alana hareketlilik ve çekicilik kazandırılmalıdır. Atatürk Köşkü Ormanında 2018 yılında yapılan çalışmalarda var olan türlere monotonluğu ortadan kaldıracak yeni türler eklenmiştir.

Bitki seçiminde yörenin mevcut iklim, toprak, su vb. yapısı dikkate alınarak bitkiler dikilirken bitkilerin ileri ki yıllarda alacağı boy ve taç genişliği de dikkate alınmalıdır. Ayrıca çim alanların tesisi ve çiçek parterleri de oluşturularak alan görsel olarak daha çekici hale getirilmelidir. Atatürk Köşkü Ormanı ve Boztepe Ormanı'nın bitkisel kompozisyonunda görülen eksikliklerine bakıldığında, Lütfi Göktaş Park'ının bitkisel tasarım açısından yeterli estetik ve işlevsel özelliklere sahip olduğu gözlemlenmiştir.

Boztepe Ormanında kapalılı̆̆ın sebep olduğu olumsuz durumları ortadan kaldırmak için bakım kesimi yapılmalıdır. Bakım kesiminde öncelikle sağlıksız, cılız fertler çıkartılmalı, meşcerede boşluklar oluşturmak için kalacak ağaçların alana düzenli dağılımı sağlanmalıdır. Kentsel yeşil alanlarda bu iyileştirme ve düzenleme çalışmaları yapılırken daha sağlıklı sonuçları elde edilebilmek için uzman kadrolar görevlendirilmelidir.

Tür seçiminde yetişme ortamı özellikleri, iklim ve türlerin morfolojik özelliklerinin iyi bilinmesi gerekir. Atatürk Köşkü Ormanı ve Boztepe Ormanı için, görsel açıdan estetik, renkli çiçeklere sahip; Crataegus spp. (alıç), Sorbus spp. (üvez), Abelia grandiflora (büyük çiçekli kelebek çalısı), Cotoneaster spp. (taş elmas1), Berberis thunbergi (hanım tuzluğu), Cornus mas (kızılcık), Nerium oleander (zakkum), Eunonymous japonicus (taflan), Syringa vulgaris (leylak), Viburnum oppulus (kartopu) gibi çalı türleri de önerilebilir. Trabzon ili iklim açısından birçok bitki türü için elverişli olduğundan bu örneklerin sayısını arttırmak mümkündür.

Boztepe Ormanı ve Atatürk Köşkü Ormanı toprak yapısına ilişkin yapılan incelemeler sonucunda alandaki toprağın kilce çok zengin, dolayısıyla ağır kil ya da balçıklı kil topraklarından oluştuğu sonucuna varılmıştır. Ağır topraklar kilce çok zengin ve sıkı olduklarından geçirimsizdirler. Dolayısıyla bitki köklerine temin ettikleri hava, daha doğrusu oksijen yetersiz kalmaktadır. Böylece kök gelişimi durmakta ve oksijensiz koşullarda ölmektedir. Bunun sonucunda ağaçlarda kurumalar gerçekleşmektedir. Ağaçlarda oluşan kurumalar bu iki ormanda görülen önemli sorunlardan biridir. Arazinin mevcut yapısını 
bozabilecek büyüklüklerden kaçınılarak teraslar halinde toprak işlemesi yapılabilir.

\section{Teşekkür}

$\mathrm{Bu}$ makale, Tuğba Pehlivan (Sevimli) tarafından KTÜ Fen Bilimleri Enstitüsü, Orman Mühendisliği Anabilim Dalı'nda hazırlanan "Kentsel Yeşil Alanların Peyzaj ve Silvikültürel Yönden Değerlendirilmesi: Trabzon Örneği” adlı yüksek lisans tezinin bir bölümüdür.

\section{Kaynaklar}

Acar, C. and Sakıcı, Ç. (2008). Assessing landscape perception of urban rocky habitats. Building and Environment, 43, 1153-1170. https://doi.org/10.1016/j.buildenv.2006.02.026.

Akalan, İ. (1987). Toprak bilgisi. Ders Kitabı, Atatürk Üniversitesi, Ziraat Fakültesi Yayınları No:1058.

Akbari, H., Davis, S. and Dorsano, S. (1992). Cooling our communities: a guidebook on tree planting and light-colored surfacing. 22P-2001. Washington. DC: U.S. Environment Protection Agency, Office of Policy Analysis, Climate Change Division.

Aksoy, Y. (2001). İstanbul kenti yeşil alan durumunun irdelenmesi. Doktora Tezi, İstanbul Teknik Üniversitesi Fen Bilimleri Enstitüsü, İstanbul.

Aksoy, Y. (2008). Landscape architecture. Ders Notları, Bahçeşehir Üniversitesi Mimarlık Fakültesi.

Anonim, (2018). Atatürk köşkü değerlendirme raporu, (Prof.Dr.Mahmut Eroğlu, Prof.Dr.Ömer Kara ve Prof.Dr.Ibrahim Turna), 17s, Trabzon.

Ceylan, A. (2007). Yaşam kalitesinin arttırılmasında kentsel yeşil alanların önemi ve kentsel dönüşüm ile ilişkilendirilmesi. Yüksek Lisans Tezi, İstanbul Teknik Üniversitesi Fen Bilimleri Enstitüsü, İstanbul.

Çakar, S. (2012). Kent ağaçlarında iyileştirme çalışmalarının değerlendirilmesi: İstanbul örneği. Yüksek Lisans Tezi, Karadeniz Teknik Üniversitesi Fen Bilimleri Enstitüsü, Trabzon.

Çepel, N. (1988). Orman ekolojisi. İstanbul Üniversitesi Orman Fakültesi Yayınları. İ.Ü. Yayın No: 3518, O.F. Yayın No.: 399. ISBN: 975 - $404-061-3$. Üçüncü Baskı, İstanbul.

Dirik, H. (1991). Kent ağaçları. İstanbul Üniversitesi Orman Fakültesi Dergisi, Seri B, Cilt 41, Sayı 3$4,69-81$.

Elinç, H. (2011). Görsel kalite değerlendirmesi yöntemi ile Antalya ili Alanya ilçesindeki Abdurrahman Alaettinoğlu ve Alanya belediye başkanları kent parklarının irdelenmesi. Yüksek Lisans Tezi, Selçuk Üniversitesi Fen Bilimleri Enstitüsü, Konya.

Gül, A. ve Küçük, V. (2001). Kentsel açık-yeşil alanlar ve Isparta kenti örneğinde irdelenmesi. Süleyman Demirel Üniversitesi Oman Fakültesi Dergisi, A2, 1302-7085, 27-48, Isparta.

Gülpınar Sekban, D. Ü., Bekar, M. ve Acar, C. (2018). Kent parklarını bitkisel tasarım yönünden değerlendirilmesi, Trabzon örneği. 1 . Uluslararası Eğitim ve Sosyal Bilimlerde Yeni Ufuklar Kongresi Bildiriler Kitabı, 9-11 Nisan 2018, İstanbul.

Kırış, K. (2009). Gümüşhane Torul yöresi saf sarıçam meşcerelerinde kalın kök kütlesi değişiminin ve bazı toprak özelliklerinin belirlenmesi. Yüksek Lisans Tezi, Artvin Çoruh Üniversitesi Fen Bilimleri Enstitüsü, Artvin.

Kowarik, I. (2011). Novel urban ecosystems, biodiversity and conservation. Environmental Pollution, $159 \quad$ (8-9), $1974-198$. https://doi.org/10.1016/j.envpol.2011.02.022.

Kuchelmeister, G. (2000). Des Abies pour millenaire urbain: le point sur le foresterie urbaine. Arbres Hors Forest, 51, 49-55, Unasylva.

Kurdoğlu, B.Ç. ve Pirselimoğlu, Z. (2011). Yol ağaçlarının anlamsal değerlendirilmesine yönelik bir çalışma. Artvin Çoruh Üniversitesi Orman Fakültesi Dergisi, 12(2), 211-221, Artvin.

McDowell, M.J. (1997). The role and application of horticultural therapy with institutionalized older people. Master Thesis, Mcgill University, Montreal.

Oğuz, D. (1998). Kent parkı kavramı yönünden Ankara kent parklarının kullanım olgusu üzerinde bir araştırma. Doktora Tezi, Ankara Üniversitesi Fen Bilimleri Enstitüsü, Ankara.

Onsekiz, D. ve Emür, S.H. (2008). Kent parklarında kullanıcı tercihleri ve değerlendirme ölçütlerinin belirlenmesi. Sosyal Bilimler Enstitüsü Dergisi, 24 (1), 69-104.

Sakıcı, Ç. (2009). Ruh ve sinir hastalıkları hastanelerinde açık alan terapi ünitelerinin peyzaj tasarımı: Ataköy (Trabzon) ruh sağlığı ve hastalıkları hastanesi örneği. Doktora Tezi, Karadeniz Teknik Üniversitesi Fen Bilimleri Enstitüsü, Trabzon.

Sakıcı, C.., Karakaş. H. ve Kesimoğlu, M. D. (2013). Kastamonu kent merkezindeki kamusal açık yeşil alanlarda kullanılan bitki materyali üzerine bir araştırma. Kastamonu Üniversitesi Orman Fakültesi Dergisi, 13(1), 153-163. 
Smardon, R.C. (1990). Perception and aesthetics of the urban environment: review of the role of vegetation. Landscape and Urban Planning, 15 (1- 2), 85-106. https://doi.org/10.1016/01692046(88)90018-7.

Tarakcı Eren, E. ve Var, M. (2016). Parkların bitkisel tasarımında kullanılan taksonlar: Trabzon kent merkezi örneği. Artvin Çoruh Üniversitesi Orman Fakültesi Dergisi, 17(2), 200-213. https://doi.org/10.17474/acuofd.71993.

Turna, İ. (2017). Kent ormancılı̆̆ alanlar). Karadeniz Teknik Üniversitesi, Orman Fakültesi, Genel yayın No:245, Fakülte Yayın No:43, 345s, Trabzon.

Turna, İ., Yazıcı, F. ve Atar, F. (2017). İstanbul ilindeki kent ağaçlarında budama çalışmalarının değerlendirilmesi. Bartın Orman Fakültesi Dergisi, 19(1), 1-10. https://doi.org/10.24011/barofd.296795.
URL-1. (2015). http://www.iha.com.tr/habertrabzonda-kisi-basi-dusen-yesil-alan-859metrekare-308501/, 27 Mart 2015.

Vural, H. (2020). Bingöl halkının yeşil alan kullanımı ve kent parkları yeterliliklerinin değerlendirilmesi. Bartın Orman Fakültesi Dergisi, 22(1), 79-90. https://doi.org/10.24011/ barofd.671442.

Yılmaz, H. (2000). Bitki tanıma ve değerlendirme II iğne yapraklı bitkiler. Ders Notları, Atatürk Üniversitesi, Ziraat Fakültesi, Erzurum.

Yuen, B. (1996). Creating the garden city: The Singapore experience. Urban Studies, 33, 955970.

https://doi.org/10.1080/00420989650011681.

Zengin, N. (2010). Giresun ili Alucra Yöresi saf ve karışık sarıçam meşcerelerinde bazı toprak özelliklerinin belirlenmesi. Yüksek Lisans Tezi, Artvin Çoruh Üniversitesi Fen Bilimleri Enstitüsü, Artvin. 